International Journal of Physical Sciences and Engineering
Available online at www.sciencescholar.us
Vol. 6 No. 1, April 2022, pages: $39-49$
e-ISSN : 2550-6943, p-ISSN : 2550-6951
https://doi.org/10.53730/ijpse.v6n1.4313

\title{
Eco-Design of an Air Conditioning System Decrease in Carbon Footprint
}

\author{
(D) crossMark \\ Ricardo Muñoz Farfán a, Telly Yarita Macías Zambrano be, German Temistocles Ramos León c, Eder \\ Israel Chinga Muentes d, Fabián Enrique Lozada Almendariz e
}

Manuscript submitted: 27 December 2021, Manuscript revised: 18 January 2021, Accepted for publication: 09 February 2022

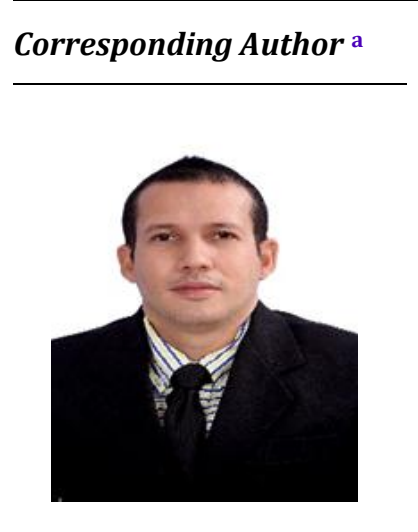

Keywords

carbon dioxide;

functional unit;

life cycle;

strategies;

sustainability;

\begin{abstract}
The appropriate use of energy is vital for the sustainable development of society in the different productive areas such as the industrial, commercial and domestic sectors, in this sense the machines must use suitable materials tending to reduce the contamination of water sources and soil, emission of carbon dioxide into the atmosphere due to energy consumption. In this context, the objective of the study focused on designing an air conditioning system based on the carbon footprint; life cycle analysis (LCA) and eco-designs were applied as a methodology, allowing to identify the categorization of the contaminant and its level of environmental impact, from the extraction of resources, manufacturing, distribution, use and final disposal. It was possible to evaluate the environmental impact referring to the functional unit of a splittype air conditioning system of 12,000 BTU of cooling capacity, obtaining as a result the carbon footprint with an annual carbon dioxide quantification of 722.8 tons of carbon dioxide. Carbon (CO2), significantly representing the intensive use of the system and, on the other hand, the energy required for the manufacturing process of the refrigerant gas hydro fluorocarbons (HFC) R410 A.
\end{abstract}

International Journal of Physical Sciences and Engineering (C) 2022. This is an open access article under the CC BY-NC-ND license (https://creativecommons.org/licenses/by-nc-nd/4.0/).

\section{Contents}

Abstract

1 Introduction..

a Instituto Superior Tecnológico Paulo Emilio Macías, Portoviejo, Ecuador

b Fuerza Apícola Montuvia, Portoviejo, Manabi, Ecuador

c Instituto Superior Tecnológico Paulo Emilio Macías, Portoviejo, Ecuador

d Instituto Superior Tecnológico Paulo Emilio Macías, Portoviejo, Ecuador

e Instituto Superior Tecnológico Paulo Emilio Macías, Portoviejo, Ecuador 


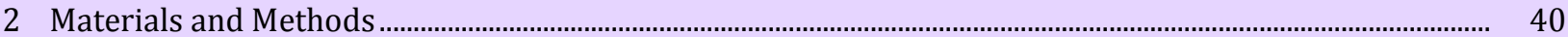

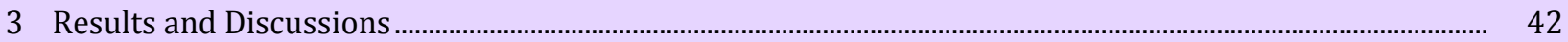

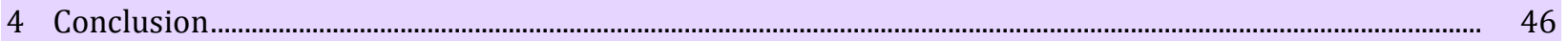

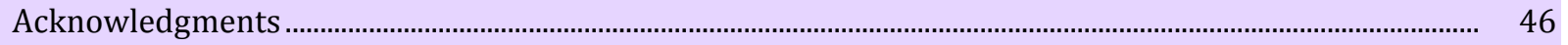

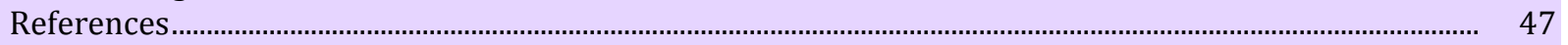

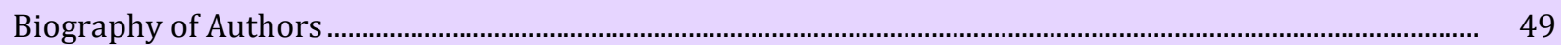

\section{Introduction}

According to the UN (2021), the world population is on the rise, in the next 30 years it is projected at 9,700 million, which makes the sustainable development of man's basic necessities vital, with the objective of guaranteeing the resources of the present and the future for the following generations. To achieve these results, life cycle analysis is necessary Ramírez et al. (2019) and improve current designs to reduce environmental impacts both in the manufacturing phase and in the use of products, essential factors for reducing pollution that affects the global world causing climate change (FAO, 2019).

Given the above, humanity is in decisive times to be able to face challenges such as climate change, having as references the various transformations that are taking place in different parts of the planet, which range from the rise in sea level to changes in the food production; due to the processes of industrialization, agriculture and large-scale deforestation, which consequently have also led to the generation of increased levels of greenhouse gases in recent years. (United Nations Organization, 2021). emissions will largely determine global mean surface warming at the end of the 21st century and beyond (see Figure SPM.10). Most aspects of climate change will endure for many centuries, even if $\mathrm{CO} 2$, implying a remarkable inexorability of climate change over several centuries, due to2 past, present and futureIntergovernmental Panel of Experts on Climate Change. Faced with this scenario, life cycle analysis, according to ISO 14040 INEN (2014), responds as part of a method that allows evaluating environmental loads from its manufacture, use and end cycle, that is, integrating the extraction raw material, production, packaging, distribution, use and final disposal of the product or service; and conclude with product improvement strategies (Cure \& Acock, 1986; Yin \& Moss, 1999).

\section{Materials and Methods}

The cradle-to-cradle life cycle-based environmental impact analysis approach was applied to the manufacture and use of split-type air conditioning systems with a cooling capacity of 12,000 BTU Avadi et al. (2015) considering the raw material, manufacturing, distribution, use and end of the product cycle Given the above, the life cycle allowed to identify and quantify the energy and materials used for the development of the product, in this context to determine the emissions of carbon dioxide (CO2) generated and that affect climate change and global warming Figure (1) shows the flowchart for product improvement with respect to the environmental impact considered.

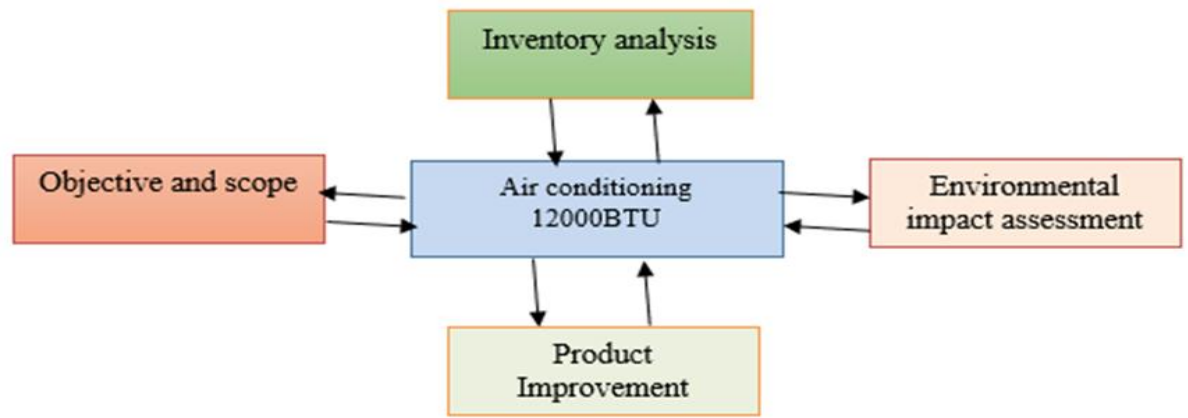

Figure 1. Product improvement flowchart 
For the evaluation of the environmental impact of the 12000 BTU split-type air conditioning product, the necessary energy in Kilowatts $(\mathrm{kW})$ of the different components of the system and their characterization have been specifically considered. according to the environmental impact category of the different components such as the compressor, evaporator, condenser, fan motor, plastics (polyethylene), copper pipes, packaging material, among others. Likewise, fuel consumption is considered by distance (km) from China to Guayaquil by means of a container ship and from Guayaquil to the assembly plant by means of trucks that transport the components of the Chigo CS12-ACR-UE brand cooling system. On the other hand, in the use of the product, the frequency of use is considered, as well as the energy required during the operation of the system and taking into consideration that the end of the cycle of the product does not have a correct final disposal, there would be the probability of an environmental impact (McKown et al., 2009; Cuff et al., 1998).

As a primary source of information, technical personnel in the air conditioning area were used, as well as suppliers of the systems involved in the manufacturing and distribution processes of air conditioning components, and on the other hand, data were used as secondary sources of information. Carbon dioxide (CO2) for each kW of energy used and fuel consumed, accepting the IPCC guidelines (Inventories, 2006). For the evaluation of the environmental impact of the product, the Eco-design PILOT software was applied, whose objective is to provide tools to improve the environmental performance of the product related to the life cycle, facilitating the formulation of improvement strategies in the production and use phase (Eco-design Pilot Corporation, 2020). Given, the eco-design program allows determining the intensity of the environmental impact caused by the product, likewise, it facilitates the integration of improvement actions.

The environmental impact assessment of the 12000 BTU split-type air conditioner product comprised two parts: characterization and classification, in this sense, the impact of greenhouse gas emissions such as $\mathrm{CO} 2$ and the characterization of resources used by categories to evaluate their impact, likewise its characterization will be classified according to the categories considered for its relevance of contamination. Table (1) shows the functional unit of the air conditioning system and the materials as part of the raw material necessary to manufacture the components of the system, the mass and its classification based on the level of pollution categorization.

Table 1

Description and manufacturing components of the product

\begin{tabular}{|c|c|c|c|c|}
\hline Name & Life time & $\begin{array}{c}\text { Functional } \\
\text { unit }\end{array}$ & Use & $\begin{array}{c}\text { Classificatio } \\
n\end{array}$ \\
\hline Air conditioning & 10 years & Chigo CS12-ACR-UE & 365 days per year & Basic type D \\
\hline Product parts & Mass (kg) & Material & Categor & \\
\hline Compressor & 18 & Iron & IV & \\
\hline Condenser & 4.5 & Aluminum & VI & \\
\hline Evaporator & 4.5 & Aluminum & VI & \\
\hline Fan motor & 3.5 & Aluminum & VI & \\
\hline Electronic board & 0.5 & Polystyrene and epoxy resin & V & \\
\hline Various plastics & 4.5 & Polystyrene & IV & \\
\hline Pipes & 0.3 & Copper & VI & \\
\hline Refrigerant gas & 1.1 & R4-10A & III & \\
\hline Package parts & Mass (kg) & Material & Category & \\
\hline Packing 1 & 1.05 & Sheet steel & IV & \\
\hline Packing 2 & 0.15 & Expanded polystyrene & IV & \\
\hline Packing 3 & 0.5 & cardboard & III & \\
\hline
\end{tabular}

Source: PILOT Eco design

On the other hand, table (2) shows the energy needed for the manufacturing production of the system components, the production volume, the percentage of external parts and their distance from where they come from are also considered; the distribution of the product with respect to maritime and land transportation and the type of packaging referring to the product, as well as the frequency of use, the energy consumption per hour and the inadequate use of the functionality of the segment

Farfán, R. M., Zambrano, T. Y. M., León, G. T. R., Muentes, E. I. C., \& Almendariz, F. E. L. (2022). Eco-design of an air conditioning system decrease in carbon footprint. International Journal of Physical Sciences and Engineering, 6(1), 39-49. https://doi.org/10.53730/ijpse.v6n1.4313 
Table 2

Manufacturing process, distribution, and use of the product

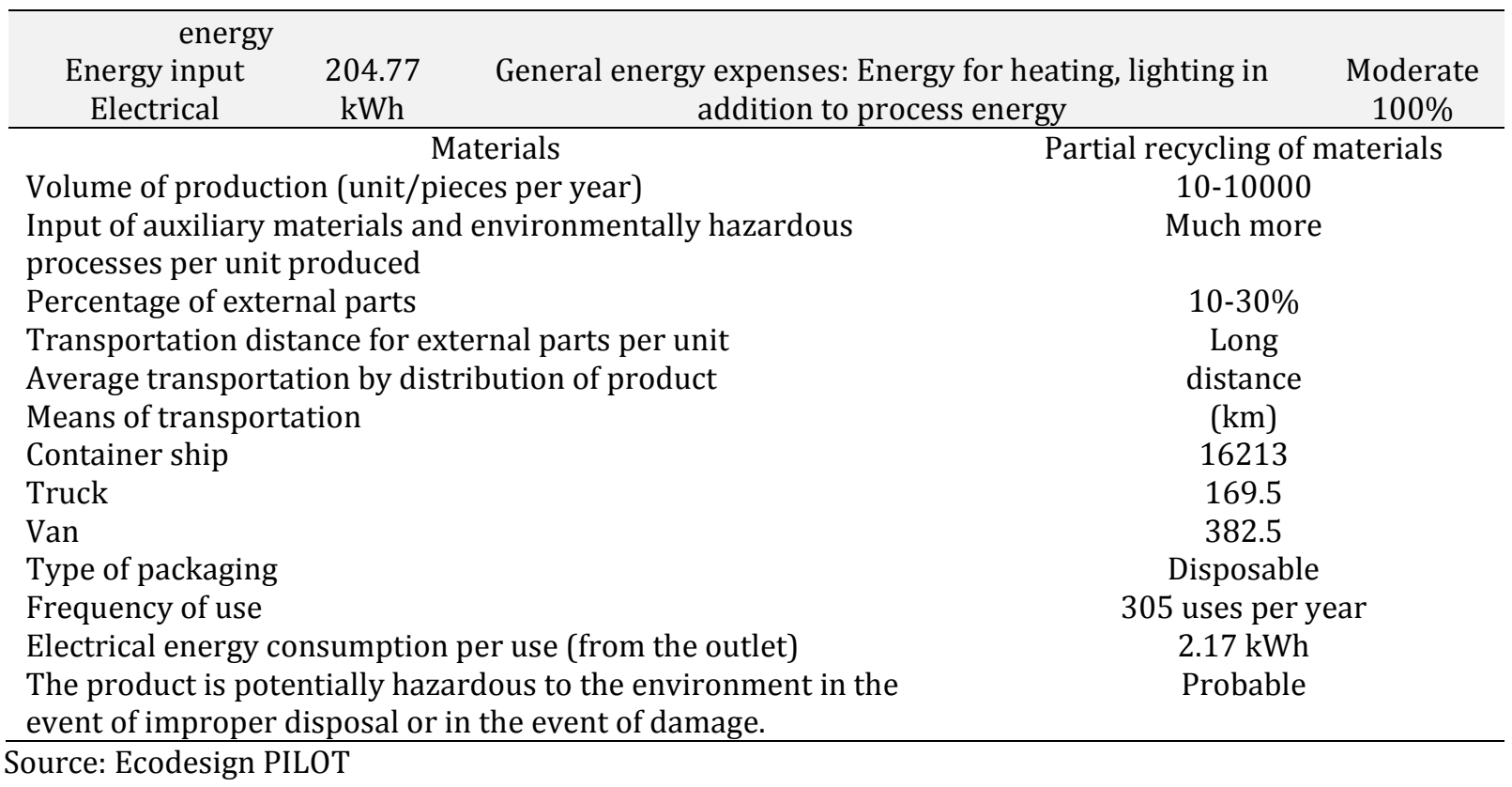

The following table (3) specifies the end of the cycle and the final disposal of the materials, many of which are recycled, reused and other hazardous waste.

Table 3

End of product life cycle Product

\begin{tabular}{cccc}
\hline Parts & Mass $(\mathrm{kg})$ & Material & Arrangement \\
\hline Compressor & 18 & Iron & Recycling \\
Condenser & 4.5 & Aluminum & Recycling \\
Evaporator & 4.5 & Aluminum & Recycling \\
Fan motor & 3.5 & Aluminum & Hazardous waste \\
Electronic card & 0.5 & Polystyrene and resin epoxy & Hazardous waste \\
Various plastics & 4.5 & Polyethylene & Reuse \\
Pipes & 0.3 & Copper & Hazardous waste \\
Refrigerant gas & 1.1 & R410A & Disposal \\
Packaging parts & Mass $(\mathrm{kg})$ & material & Recycling \\
Packaging 1 & 1.05 & Sheet steel & Hazardous waste \\
Packaging 2 & 0.15 & Expanded polystyrene & Recycling \\
Packaging 3 & 0.5 & Cardboard &
\end{tabular}

\section{Results and Discussions}

\section{Importance of eco-design studies of air conditioning}

In the coastal and eastern regions of Ecuador, high temperatures and humidity are recorded, especially in winter National Institute of Meteorology and Hydrology (2021), which causes inadequate thermal comfort,. Ecuadorian Social Security (1986), effect that not only has an impact on the work environment, but also influences the health of the worker, especially when, at the business level, the concept of a good work 
environment is a trend that is gaining importance to ensure the health of workers. Workers and increase productivity, according to the study carried out by the Social Market Foundation (2021); University of Warwick (2021), which reveals the way in which appropriate spaces motivate a good working environment among collaborators (Curran, 2013; Ramesh et al., 2010).

In this sense, the company's air conditioning systems are essential, many of which use air conditioning equipment with variable cooling capacities to meet the needs of work comfort; Among the most used are those with a capacity of 12,000, 18,000 and 24,000 BTU both in the domestic and commercial sectors and also for certain areas of industry such as administrative departments. All this equipment has an energy consumption, which is linked to the rate of carbon dioxide emission, from which the concept of Eco design starts, which has a direct implication on the products due to its relationship between the social, economic and ecological throughout the life cycle, especially when they exert environmental impacts such as greenhouse gas emissions, smoke or water eutrophication; reasons why an analysis of the product life cycle is essential, allowing to optimize the product and consequently reduce the negative impact of the air conditioning system on the environment and on the business economy and society (Encinas Malagon, 2011).

It is also important to consider that the environmental impact analysis studies for air conditioning system products are very few, so the authors could not compare and evaluate the environmental impact that they can generate according to categories such as climate change, ozone depletion, human toxicity, Eco toxicity, ionizing radiation, photochemical ozone formation, eutrophication, acidification, and soil depletion. In this virtue, the objective of the study was framed in designing a split type air conditioning system of $12000 \mathrm{BTU}$ considering the carbon footprint of the product, within the framework of the category of global warming due to the effect of carbon dioxide (CO2).

Once the cradle-to-cradle life cycle analysis was carried out, strategies were generated to be followed to optimize the manufacturing, functionality and final disposal of the product, thus, as high priority strategies, the performance of environmental safety must be guaranteed and consumption reduced in the stage of use; additional strategies such as optimizing product functionality, improving maintenance; and furthermore, future strategies such as optimization of the type and quantity of process materials and green procurement of external components. The results of the calculation of the carbon footprint referring to the product of the conventional 12,000 BTU split-type air conditioning system are shown in table (4).

Table 4

Emissions of $\mathrm{CO}_{2}$ produced by equipment

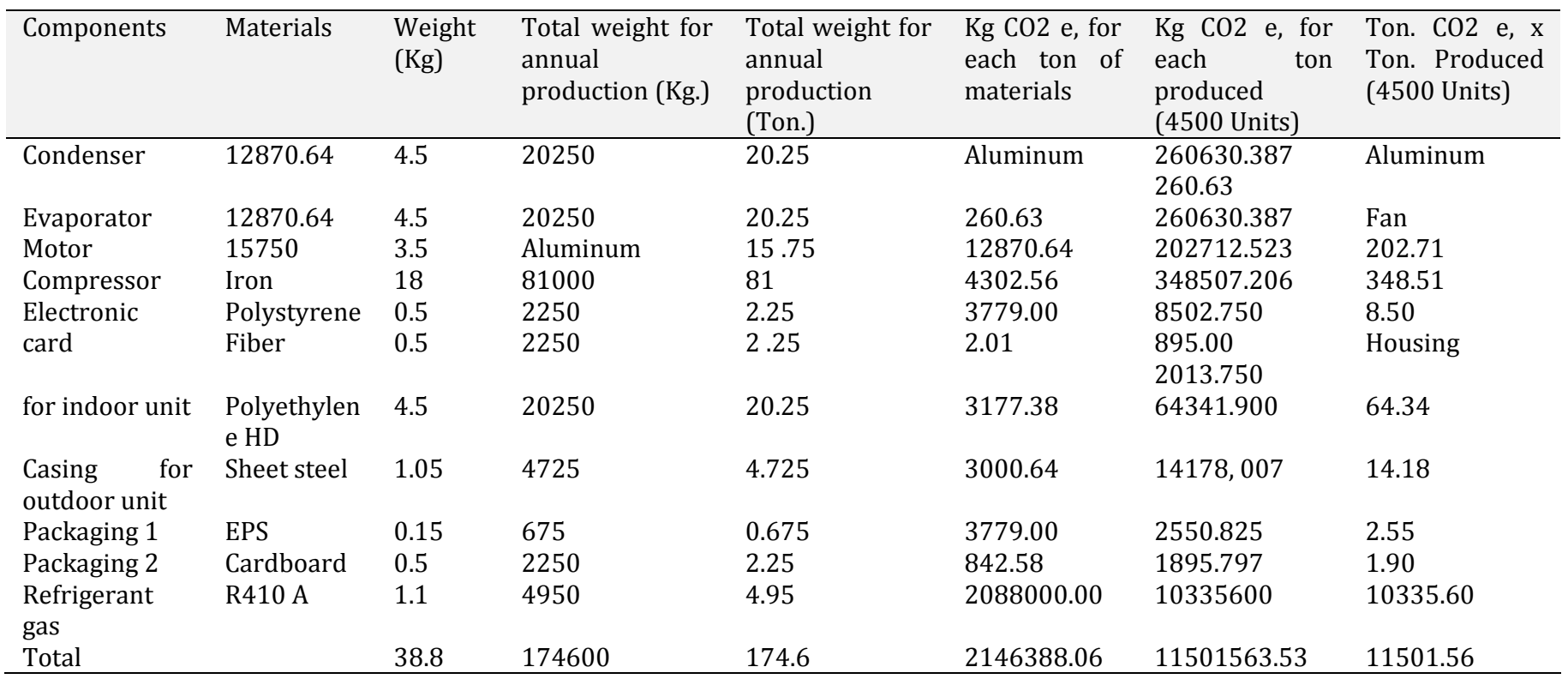

Farfán, R. M., Zambrano, T. Y. M., León, G. T. R., Muentes, E. I. C., \& Almendariz, F. E. L. (2022). Eco-design of an air conditioning system decrease in carbon footprint. International Journal of Physical Sciences and Engineering, 6(1), 39-49. https://doi.org/10.53730/ijpse.v6n1.4313 
Considering the manufacture, distribution, and use of the components of the air conditioning product, it was possible to quantify carbon dioxide emissions $\mathrm{CO}_{2}$, considering that the refrigerant gas has the largest hue lla of carbon (10,335.60 Ton $\left.\mathrm{CO}_{2}\right)$ equivalent per ton produced (4,500 units). Emissions from maritime transport, truck land transport, distribution land transport and equipment in operation.

Table 5

Emissions of $\mathrm{CO}_{2}$ by sea, land by Truck, land in distribution and by equipment in operation

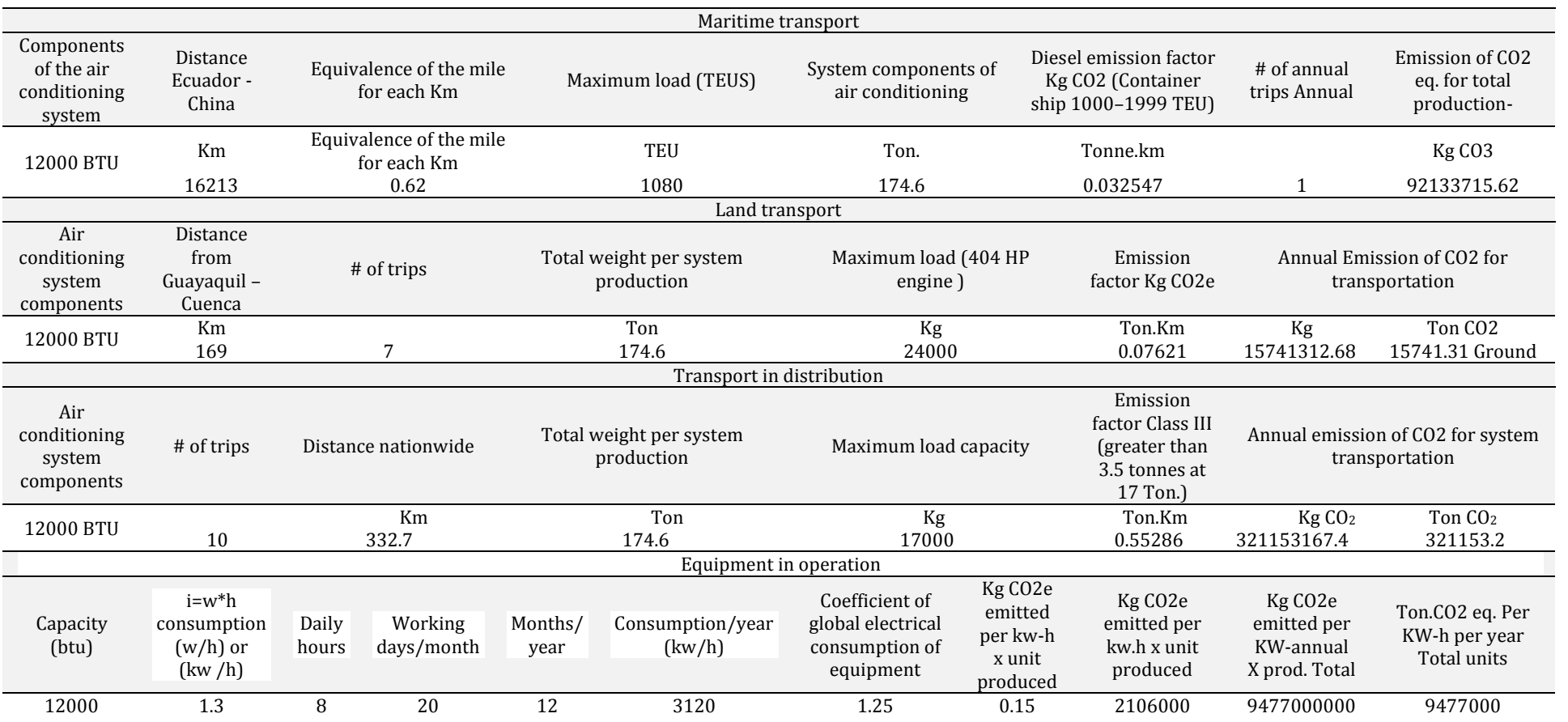

The highest $\mathrm{CO}_{2}$ emission falls on maritime transport (92133.72 $\mathrm{Ton}^{\mathrm{CO}_{2}}$ e) of annual emission per total production, however, the equipment in operation (air conditioning) generates high $\mathrm{CO}_{2}$ emissions (9 477000 ) per $\mathrm{kWh}$ in the year. The carbon footprint of the product in its production phase and by its functional unit is shown in the table (6).

Table 6

Carbon footprint of the cooling system by production and by functional unit

\begin{tabular}{|c|c|c|c|c|c|c|}
\hline \multicolumn{3}{|l|}{ By production } & \multicolumn{4}{|l|}{ By functional unit } \\
\hline $\begin{array}{l}\text { Carbon footprint of the conventional } \\
\text { air conditioning system } 12,000 \text { BTU }\end{array}$ & $\begin{array}{l}\text { Ton. } \mathrm{CO} 2 \\
\text { equivalent. } \\
\text { annual } \mathrm{x} \text { total } \\
\text { units }\end{array}$ & $\begin{array}{l}\text { Ton. CO2 equivalent. } \\
\text { yearly cradle to door } \\
\text { * functional unit }\end{array}$ & $\begin{array}{l}\text { Ton. } \\
\text { equivalent } \\
\text { functional unit } \\
\text { (Cradle to door) }\end{array}$ & $\begin{array}{l}\text { Ton. CO2 equivalent. } \\
\text { (Cradle to cradle) } \\
\text { annual * functional unit }\end{array}$ & $\begin{array}{l}\text { Ton. } \\
\text { equivalent. } \\
\text { cycle (years) }\end{array}$ & $\begin{array}{l}\mathrm{CO} 2 \\
\text { Life }\end{array}$ \\
\hline Manufacture of the equipment & $11,501.56$ & & 2.56 & & & \\
\hline Maritime transport & $92,133.72$ & & 20.47 & & & \\
\hline Land transport by import & $15,741.31$ & & 3.50 & & & \\
\hline Land transport by distribution & $321,153.17$ & & 71.37 & & & \\
\hline Energy required during its operation & $9477,000,00$ & & 2106.00 & 16848.00 & & \\
\hline Total CO2 & 9917529.76 & 2203.90 & 2203.90 & 16848.00 & 19051.90 & \\
\hline
\end{tabular}

The highest carbon footprint generated by the product corresponds to the production stage, when the energy required for its operation, it is the highest value $(9,477,000$ Tons of CO2) equivalents for total units produced in the year, while the functional unit emits 19,051.9 Tons of CO2 equivalents to the life cycle of the product, which is 10 years (Kumar \& Lin, 2010; He et al., 2019). As part of the life cycle analysis, the product is considered type D with respect to the Eco-design Pilot software, that is, the intensive consumption of energy 
and materials during use, dominating the environmental performance of the product. Carbon dioxide $\left(\mathrm{CO}_{2}\right)$ from the 4,500 units produced annually is 11,501.6 Tons of CO2 equivalent. Emissions from transportation are significant, reaching 429,124.3 tons of carbon dioxide (CO2) equivalent for the 4,500 units produced annually. In relation to the use of the cold system, carbon dioxide emissions (CO2) for the total of 4,500 units in annual operation is 2,812,320.0 Tons of CO2 equivalent considering 8 hours per day for 20 days and 365 days anus (Kasiani \& Yusuf, 2019; Omer, 2015). The carbon footprint for the 12,000 BTU capacity air conditioning Functional Unit is 722.88 Tons of CO2 equivalent per year. Figure (1) shows the energy consumption of the product per functional unit.

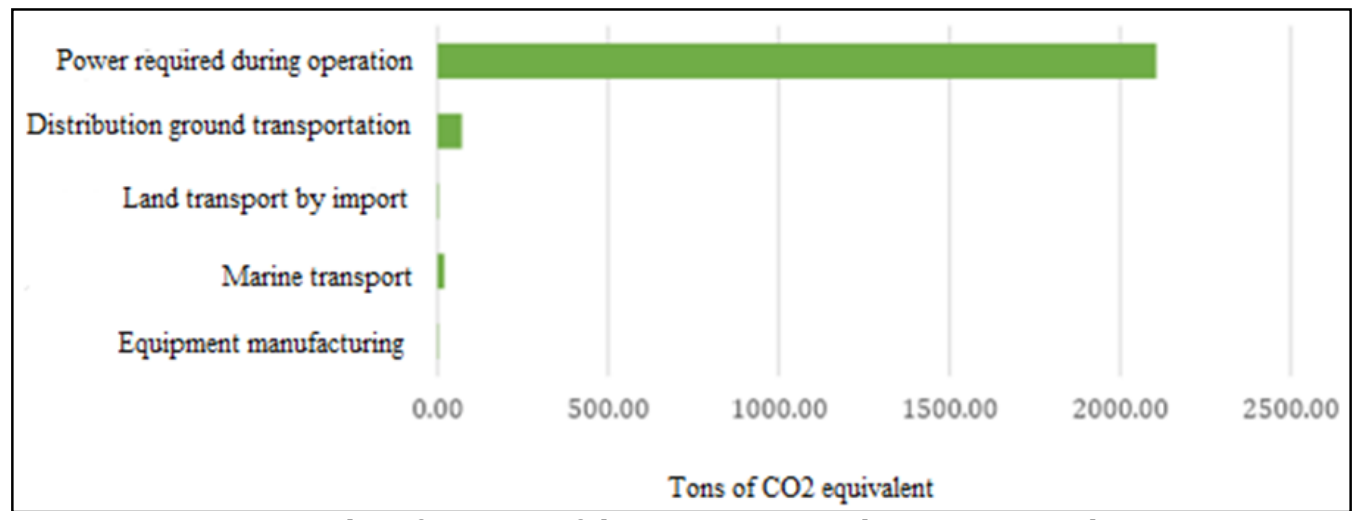

Figure 1. Carbon footprint of the 12,000 BTU split-type air conditioner

In this sense, the cradle-to-cradle life cycle analysis addressed by the Eco design PILOT simulator yields data on the impact category of the type of intensive use regarding the consumption of energy and materials in its manufacturing process of its components that make up the system, as well as the refrigerant gas that is used as a means of transformation to transfer energy from one source to another with an energy consumption of 11,501.56 Tons of CO2 equivalent per year that corresponds to the total of the manufacturing components and supplies. Faced with this, the United Nations Organization stands for peace, dignity and equality on a healthy planet, presents the challenges of climate change, among which is the human footprint, especially in the presence of greenhouse gases, such as carbon dioxide (CO2), being the gas with the highest concentration in the atmosphere, constituting approximately two thirds of the presence of other gases.

On the other hand, the Kyoto protocol corresponds to the United Nations Framework Convention on Climate Change (UNFCCC), and an international agreement that aims to "reduce emissions of six greenhouse gases that cause global warming: dioxide of carbon (CO2), methane gas (CH4) and nitrous oxide (N20), and three other fluorinated industrial gases: hydro fluorocarbons (HFCs), per fluorocarbons (PFCs) and sulfur hexafluoride (SF6)". In accordance, the UN Climate Action Summit in 2019 welcomed nine priority action areas and new significant and concrete commitments to combat the climate crisis, considering solutions and concrete plans in terms of global transition towards renewable energy, infrastructure, and sustainable cities. Resilient, agriculture and sustainable management of oceans and forests, resilience and adaptation to climate impacts and convergence of public and private financing with a net zero emissions economy (Jin et al., 2017; Schaltegger \& Csutora, 2012).

In the same context also, the Paris Agreement mentions the use of new technologies improving energy efficiency, products, implementation of ecological solutions, sustainable industry with the reduction of carbon emissions and the development of good manufacturing practices and equipment maintenance. Of air conditioners, as well as in the correct handling of refrigerant gases CFC, HFC as they are potential greenhouse gases and deteriorate the ozone layer (BBC NEWS, 2021; León \& Benavides, 2007). Thus, the development of high energy efficiency equipment throughout the life cycle of the air conditioning system from the raw material to its point of operation becomes very important, since in this particular case the energy required for its operation is significant. The environmental impact assessment of the products is based on the results obtained, allowing to know the level of environmental contamination and opt for new products under new strategies that generate less impact on the environment, improving products of small, medium and large-scale

Farfán, R. M., Zambrano, T. Y. M., León, G. T. R., Muentes, E. I. C., \& Almendariz, F. E. L. (2022). Eco-design of an air conditioning system decrease in carbon footprint. International Journal of Physical Sciences and Engineering, 6(1), 39-49. https://doi.org/10.53730/ijpse.v6n1.4313 
consumption. Contributing to the industry and its competitiveness in the market, in short, industrial design must be equal to eco designs that harmonize environmental criteria with product designs with the aim of satisfying the needs of society and caring for the environment (ECO intelligence, 2015).

\section{Conclusion}

As conclusions of this ecodesign study of an air conditioning system with a cooling capacity of $12,000 \mathrm{BTU}$, it has been possible to provide relevant information on the carbon footprint generated by the manufacture and use of this product. life cycle analysis determined a category of environmental impact of type "D" related to greenhouse gases such as carbon dioxide $\mathrm{CO} 2$, denoting a high energy consumption, which promotes global warming. Therefore, it is essential to consider environmental safety strategies such as reducing the use of this type of cooling system due to the high $\mathrm{CO} 2$ it emits into the atmosphere; In addition, it is recommended to develop technified preventive maintenance, tending to reduce the corrective and consequently reduce possible leaks of refrigerant gas from the system, on the other hand, cutting-edge technologies should be acquired that allow the efficient operation process of the system to be controlled.

\section{Acknowledgments}

To all the people who supported in the realization of the paper, in addition to the editors of the journal. 


\section{References}

Avadí, A., Bolaños, C., Sandoval, I., \& Ycaza, C. (2015). Life cycle assessment of Ecuadorian processed tuna. The International Journal of Life Cycle Assessment, 20(10), 1415-1428.

BBC NEWS. (2021). CFC gases in the atmosphere.

Cuff, M. E., Miller, K. I., van Holde, K. E., \& Hendrickson, W. A. (1998). Crystal structure of a functional unit from Octopus hemocyanin. Journal of molecular biology, 278(4), 855-870. https://doi.org/10.1006/jmbi.1998.1647

Cure, J. D., \& Acock, B. (1986). Crop responses to carbon dioxide doubling: a literature survey. Agricultural and forest meteorology, 38(1-3), 127-145. https://doi.org/10.1016/0168-1923(86)90054-7

Curran, M. A. (2013). Life cycle assessment: a review of the methodology and its application to sustainability. Current Opinion in Chemical Engineering, 2(3), 273-277. https://doi.org/10.1016/j.coche.2013.02.002

ECO intelligence. (2015). Ecodesign in industry.

Ecodesign pilot corporation. (2020). Seitenan fang design and copyright by Vienna YOUR Institute for Engineering Design - ECODESIGN.

Ecuadorian Institute of Social Security. (1986). regulation of Safety and Health of workers and improvement of the Work Environment. Quito, Ecuador.

Encinas Malagon, MD (2011). Environment and pollution.

FAO. (2019). fao.org.

He, Y., Zhuang, X., Lei, C., Lei, L., Hou, Y., Mai, Y., \& Feng, X. (2019). Porous carbon nanosheets: synthetic strategies and electrochemical energy related applications. Nano Today, 24, 103-119. https://doi.org/10.1016/j.nantod.2018.12.004

INEN. (2014). Environmental Management: Life Cycle Analysis Principle and Reference Framework. Quito, Ecuador: INEN.

Inventories, TF. (2006). Intergovernmental Panel on Climate Change. U.S.

Jin, M., Tang, R., Ji, Y., Liu, F., Gao, L., \& Huisingh, D. (2017). Impact of advanced manufacturing on sustainability: An overview of the special volume on advanced manufacturing for sustainability and low fossil carbon emissions. Journal of cleaner production, 161, 69-74. https://doi.org/10.1016/j.jclepro.2017.05.101

Kasiani, .-., \& Yusuf, M. (2019). Developing ergonomics-based practice system to improve students' typing skills. International Research Journal of Engineering, IT \& Scientific Research, 5(4), 28-37. https://doi.org/10.21744/irjeis.v5n4.688

Kumar, M., \& Lin, J. G. (2010). Co-existence of anammox and denitrification for simultaneous nitrogen and carbon removal-strategies and issues. Journal of Hazardous Materials, 178(1-3), 1-9. https://doi.org/10.1016/j.jhazmat.2010.01.077

León, G. E., \& Benavides, H. O. (2007). Información técnica sobre gases de efecto invernadero y el cambio climático. Instituto de Hidrología, Meteorología y Estudios Ambientales-IDEAM. Fecha de consulta, 20(10), 2019.

McKown, R. L., Wang, N., Raab, R. W., Karnati, R., Zhang, Y., Williams, P. B., \& Laurie, G. W. (2009). Lacritin and other new proteins of the lacrimal functional unit. Experimental eye research, 88(5), 848-858. https://doi.org/10.1016/j.exer.2008.09.002

National Institute of Meteorology and Hydrology. (2021). Meteorology and Hydrology in Ecuador.

Omer, A. M. (2015). Performance, modeling, measurements, and simulation of energy efficient for heat exchanger, refrigeration and air conditioning. International Research Journal of Engineering, IT \& Scientific Research, 1(1), 24-44. Retrieved from https://sloap.org/journals/index.php/irjeis/article/view/235

Ramesh, T., Prakash, R., \& Shukla, K. K. (2010). Life cycle energy analysis of buildings: An overview. Energy and buildings, 42(10), 1592-1600. https://doi.org/10.1016/j.enbuild.2010.05.007

Ramirez, A. D., Rivela, B., Boero, A., \& Melendres, A. M. (2019). Lights and shadows of the environmental impacts of fossil-based electricity generation technologies: A contribution based on the Ecuadorian experience. Energy policy, 125, 467-477.

Schaltegger, S., \& Csutora, M. (2012). Carbon accounting for sustainability and management. Status quo and challenges. Journal of Cleaner Production, 36, 1-16. https://doi.org/10.1016/j.jclepro.2012.06.024

Social Market Foundation. (2021). Public Services.

Farfán, R. M., Zambrano, T. Y. M., León, G. T. R., Muentes, E. I. C., \& Almendariz, F. E. L. (2022). Eco-design of an air conditioning system decrease in carbon footprint. International Journal of Physical Sciences and Engineering, 6(1), 39-49. https://doi.org/10.53730/ijpse.v6n1.4313 
UN. (2021). Ecodesign for Industrial Development. Vienna, Austria: United Nations.

UN. (2021). Peace, dignity and equality in a healthy planet. United States of America: UN.

United Nations. (2021). Climate change. U.S.

University of Warwick. (13 of 03, 2021). University of Warwick.

Yin, X., \& Moss, J. R. (1999). Recent developments in the activation of carbon dioxide by metal complexes. Coordination Chemistry Reviews, 181(1), 27-59. https://doi.org/10.1016/S00108545(98)00171-4 


\section{Biography of Authors}

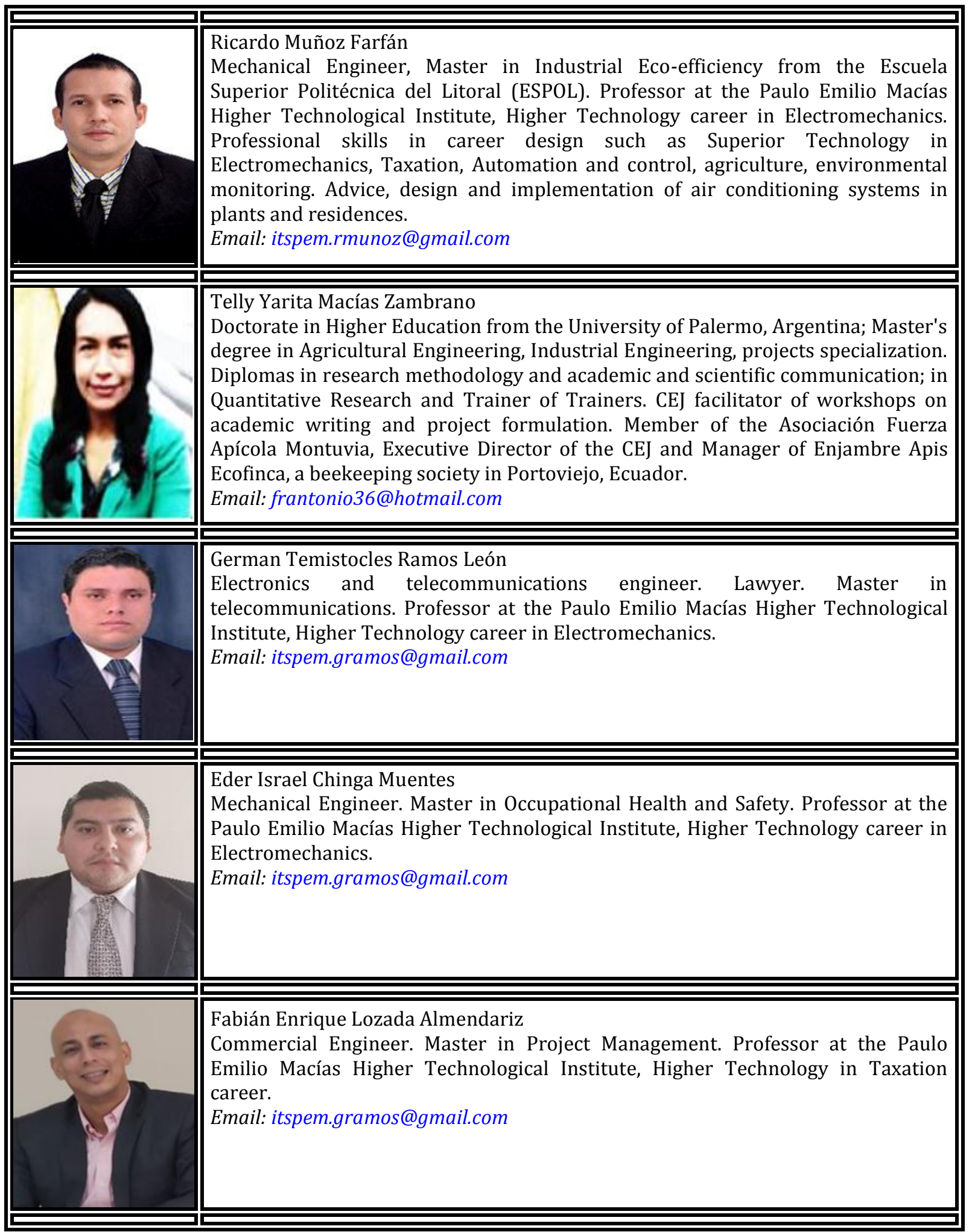

Farfán, R. M., Zambrano, T. Y. M., León, G. T. R., Muentes, E. I. C., \& Almendariz, F. E. L. (2022). Eco-design of an air conditioning system decrease in carbon footprint. International Journal of Physical Sciences and Engineering, 6(1), 39-49. https://doi.org/10.53730/ijpse.v6n1.4313 